\title{
Reading Turcophilia: The Turkish Life of Pierre Loti in Aziyadé and Fantôme d'Orient
}

\author{
Hacer Esra ALMAS ${ }^{1}$ []
}

${ }^{1}$ Assist. Prof., Ihsan Dogramaci Bilkent University, Department of Turkish Language and Literature, Ankara, Turkey

ORCID: H.E.A. 0000-0002-7773-8615

\section{Corresponding author:}

Hacer Esra ALMAS,

Ihsan Doğramacı Bilkent Universitesi, Türk Edebiyatı Bölümü, Ankara, Türkiye E-mail: esra.almas@gmail.com

Submitted: 14.01 .2021

Revision Requested: 24.02.2021 Last Revision Received: 15.04.2021 Accepted: 30.04 .2021

Citation: Almas, H. E. (2021). Reading turcophilia: The Turkish life of Pierre Loti in Aziyadé and Fantôme d'Orient. Litera, 31(2), 587-603.

https://doi.org/10.26650/LITERA2021-860740

\begin{abstract}
Aziyadé (1879) and Fantôme d'Orient (1891), an autobiographical debut novel and a travel narrative by Pierre Loti, are key texts in French exoticist literature. Set in the Ottoman Empire on the eve of its disintegration, Loti's debut novel illustrates a young man's discovery of life à la turque through an account of his stay in Istanbul and his liaison with Aziyadé, a young married Turkish woman from a harem. The affair ended with his departure, but Loti's fondness for Istanbul remained. He returned to the city ten years later, as a best-selling literary writer and a member of the Academie Française, to seek the traces of his past. Fantôme d'Orient is the account of his three-day stay in search of his Turkish life and a self-reflexive meditation on memory, loss, death, and distance. Loti's Turkish persona and profound attachment to the country raise questions on affect and affinity, or on what it means to write as a Turcophile. Taking its cue from the links among exoticism, imperialism and travel writing, this paper illustrates the personal, the political, and the poetic implications of Loti's assumed Turkish identity. Focusing on affect and rhetoric, it seeks to answer how affinity shapes discourses conditioned by power and empire, highlighting its poetic potential and political sensibilities.
\end{abstract}

Keywords: Travel writing, memory, orientalism, Istanbul, exoticism 


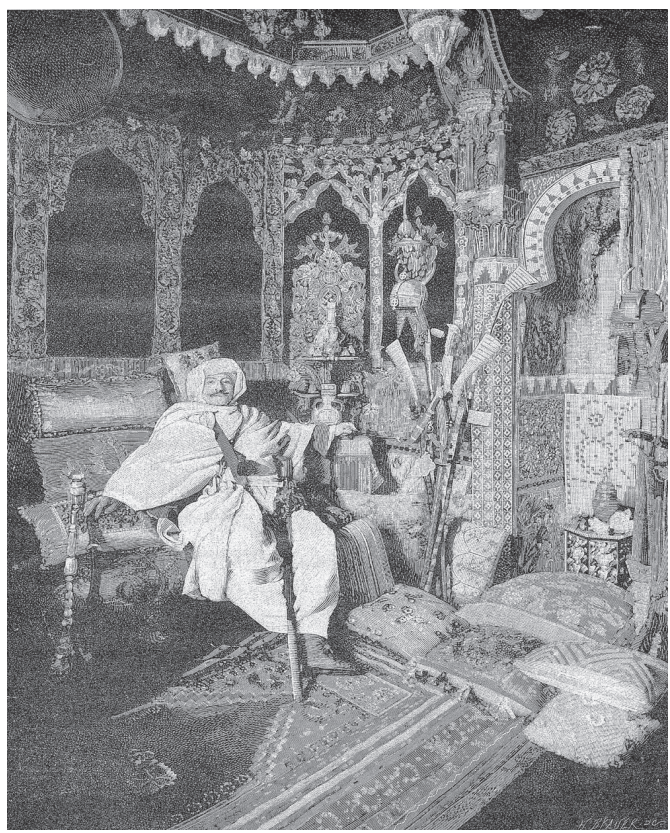

The Turkish Room (Genet and Hervé, 1988, p. 342)

\section{Introduction}

\section{a. The Turkish Room}

The above photograph displays an Oriental room. Its lush trimmings, ranging from the Oriental style drapery, embroidered pillows and carpet, a niche decorated with geometric tiles and a coffee table inside its recess, a hookah on the left are all characteristic of Middle Eastern interiors. The objects seem genuine; the room, however, seems feigned. The room is defined by the man in the center, a Westerner in a Bedouin costume. His fair skin and well-groomed belle époque moustache contrast with his outfit, highlighting the ambiguity of his position with regard to two traditions. The depiction of a Western male enjoying the voluptuous luxury of the East evokes Oriental fantasies, or the décor of a Hollywood movie set in the Middle East. This is the 'Turkish Room' of Pierre Loti in his mansion in Rochefort, France, which pays homage to his life in Istanbul, the subject of his debut novel Aziyadé (1879). The experience informed Loti's career and character. The affair ended with Loti's departure, but his fondness for the Turks continued, as did his representations. The Turkish room was built upon his return to France from Turkey, during the writing of Aziyadé, in an attempt to create a space to 
dream of Turkey, hence materializing the memory (Armbrecht 2003, p. 88). Architecture sustained text as Loti's Turkish connection persisted: Fantôme d'Orient, published in 1891 , recounts his brief second visit to Istanbul, this time as the renowned French writer in search of his past life.

The photograph shows Loti recreate, take part in, and turn into what once constituted the object of his gaze. The Turkish room is not only a place, but also a site of cultural meaning and emotional attachments. When fondness turns into affinity, it raises questions about affect. The significance of Aziyadé and Fantôme d'Orient is not only their autobiographical quality, but the author's Turcophilia'. The writer's sympathy led to a new identity, which in turn forged a new life and a new perspective. This essay focuses on Loti's rhetoric: the role of affect and allegiance on writing the Other within an imperialist context (Pratt, 2008). It opens with an account of Loti's Turcophilia as it impacted his career, followed by a brief description of exoticism as a condition of his gaze. Next in focus is Aziyadé, the genesis of Loti's Turkish passion, converging love and the orient, while interpreting an orientalist stereotype - death and decay. The paper ends with Fantôme d'Orient, the closure to Aziyadé, to nuance the role of memory and mourning, and the understated cosmopolitanism in his vision of the Orient. Situating the poetics of Loti's Turkish identity in both narratives within discussions of travel and empire, this study highlights affect as poetic potential and political sensibility.

\section{b. The Career of a Turcophile Writer}

The life and the work of Julien Viaud, or Pierre Loti as he chose to be known as, exemplify the exoticism of the Belle Époque. Loti's position as a naval officer provided him with opportunities to travel to distant and 'exotic' lands, including Turkey, Tahiti and Japan. Through the pseudonym he chose for both his attributes, the author-narrator and the central figure in his novels, Loti embarked on a literary career that outshone the former one, including membership to the prestigious Académie Française in 1891. For Loti, the experience of Turkey was decisive both emotionally and artistically. His literary career started with the publication of Aziyadé in 1879. An epistolary account of an English naval officer's sojourn in Ottoman Turkey and his liaison with Aziyadé, a young married Turkish woman from a harem, the roman a clefillustrates a young man's discovery of life à la turque. Loti's departure put a stop to his life in Istanbul, but not his

1 The following references and page numbers refer to the Folio 1991 edition, Aziyadé suivie par le fantôme d'Orient. 
fondness for the Turks. The writer returned to Istanbul for a brief visit, in search of the traces of his Turkish life, published as Fantôme d'Orient, (1891). By then, Loti's attachment for the Ottoman Empire had crystallized into a peculiar patriotism of Istanbul. For the French publishing house Hachette, he penned an essay on Istanbul as one of the capitals of the world, entitled Constantinople 1890. Loti later referred to the essay as his patriotic duty (Quella-Villéger, 2002, p. 334).

Loti's last novel on the Ottoman Turks, Les Désenchantées (1906), depicted once more the women of harems, this time with the aim of voicing, and thereby contributing to the remedy of their suffering. "This story contains no facts except the extensive high culture in the Turkish harems and the suffering that results from it," Loti bemoans, adding that it is a concern his Turkish friends are already working on (Loti, 1924)2. This literary adventure, reminiscent of earlier narratives, provides an alternate lens to Loti's commitment to Ottoman Turkey and is worth a parenthesis. The novel is based on the encounters between Pierre Loti and two Ottoman aristocrats, Zeyneb and Melek Hanoum, the adopted names of Hatice Zennur Hanım and her sister Nuriye Hanım, the daughters of Nuri Bey, the minister of foreign affairs. The sisters had a French connection as they were the granddaughters of Marquis de Blosset de Chateauneuf, a French nobleman who came to Istanbul during the Crimean War, converted to Islam, and stayed in the city (Lewis, 2004, pp. 19-24). The sisters were familiar with French letters, in particular with the reputation of Loti, and wanted to make use of it in favor of Ottoman women's plight. They presented themselves to Loti as Zeyneb and Melek Hanoum and persuaded the writer that a third woman in their company, Maria Léra, a French journalistwriter, who disguised herself with a veil and adopted a Turkish name, Djenan, was desperately in love with him (Lewis, 2004). Loti was completely taken in by the three women. Their meetings and correspondence led to Les Desenchantées, a novel on a desolate love affair featuring Zeyneb, Melek, and Djenan Hanoum and himself, thinly disguised as the renowned French writer André Lhery, and carrying on the tradition of roman a clef. The'real' plot behind the novel was disclosed after Loti's death, in conflicting accounts, first by Maria Léra, this time writing under the pseudonym Marc Hélys, in her work Le secret des désenchantées (Hélys, 1923). Zeyneb Hanoum's letters reveal the intricate plotting on the part of the Turkish sisters (Lewis, 2004).

2 "Il n'y a de vrai [dans cette histoire] que la haute culture intellectuelle répandue aujourd'hui dans les harems de Turquie, et la souffrance qui en résulte... (m)es chers amis les Turcs s'en inquiètent déjà et voudraient l'adoucir." All translations in this article are by the author. 
Later in life, Loti followed a different path in his representations of the Turks, letting his attachment define his literary and political life. The rapid disintegration of the Ottoman Empire on the eve of the First World War led him to defend the Turks. He launched a campaign to win French support for La Turquie agonisante, the title of a collection of articles and letters that Loti published in $1913^{3}$. This unconditional political support would bring Loti the admiration of the Turks, traditionalists and republicans alike. The Crown Prince Abdulmecid II founded The Pierre Loti Society in 1920 as a means of popularizing the French author's works and translating them into Turkish (Şerifoğlu, 2004). A year later, in December 1921, Loti received a Turkish delegation in Rochefort representing the Turkish republican movement, founded in opposition to the Ottoman Empire and to the Allied victors of World War I, who occupied the country. The delegation brought Loti a letter of homage from Mustafa Kemal (Atatürk), the president of the Grand National Assembly, and a present, to "bear witness to the profound and unalterable friendship that the Turkish people felt towards the Great Master who, with his magic pen, have defended their rights even in the darkest hour" (Loti, 1991, p. 348) ${ }^{4}$. Loti's health was already failing, and he did not live to see the founding of the Turkish Republic in 1923.

\section{Aims and Methods: Reading Exoticism}

With its state officially bankrupt in 1875, the Ottoman Empire at the turn of the twentieth century was increasingly under the control of its creditors, notably France, Britain, and Germany, and referred to as "the sick man of Europe."The Empire was also the only sovereign Muslim state that took part in the alliances among Western European empires (Deringil, 2003, p. 316). The ambiguity of the Ottoman Empire makes exoticism the primary reflection of the Westerner's experience. Combining fiction and ethnography, at the very outset, exoticism reflects the colonial gaze, and hinges on the difference of the'West'from the rest ${ }^{5}$. Exoticism is characterized by descriptive narrative, preconditioned perceptions, and superficial knowledge of the country. It is defined as "the touching personal literature of the sensitive [European] traveler" who, seeking unusual impressions, transforms his object into a quasi-imaginary realm of eccentricity, surprise, and diversion

3 Les Massacres d'Arménie (The Massacres in Armenia, 1918), and Les Alliés qu'il nous faudrait (The Allies We Need, 1919) were his final pamphlets in support of Ottoman Turkey.

4 "témoigner de la profonde et inaltérable amitié du Peuple turc envers l'Illustre Maître qui, de sa plume magique, a, dans les plus sombres jours de son histoire, défendu ses droits."

5 This understanding of colonial literature takes its cue from the definition of colonialism as "all the culture affected by the imperial process from the moment of colonization to the present day" (Ashcroft, Griffiths, Tiffin, 1989, p. 2). 
(Moura, 1997, 114) $)^{6}$. Within the context of nineteenth-century imperialism, exoticism reflects the rhetoric of empire which, in Mary Louise Pratt's words, refers to "the strategies of representation whereby European bourgeois subjects seek to secure their innocence in the same moment as they assert European hegemony" (Pratt, 2008, p. 9).

The work of Pierre Loti is regarded as some of the finest examples of French exoticism. His numerous novels, based on his journeys, convey his desire to capture his fleeting impressions and pleasures mixing with the locals and adopting their cultures (Hargreaves, 1981; Quella-Villéger, 2002). His work, part memoir, part travel reportage, speaks to the imaginary of the period, notably the rhetoric of empire (Pratt, 2008; Spurr, 1999). As a naval officer, he was part of the civilizing mission of France, if not a representative of French interests and imperialist policies. Nonetheless, his work is not a celebration of the white man's burden in the manner of Rudyard Kipling, but rather a lamentation of the loss of the East, a precursor to an affirmation of Tristes Tropiques, to paraphrase Claude Lévi-Strauss (Lévi-Strauss, 1955). In the years Loti visited the Ottoman Empire, Istanbul was still the capital of the Orient. Loti therefore did not refrain from referring to Ottoman Turkey as his patrie orientale. The idea of a second homeland conveys not only an appropriation of the other, but also a claim to be its offspring and 'subject,'; however, ambiguous belonging and subjecthood might seem. His identification as a Turk makes him a sympathetic writer, one who would be likely to question reductionist representations, and perhaps to provide an "internal imperialist critique of empire" (Pratt, 2008, p. 206), while employing a rhetoric of presence. Nonetheless, Loti's fascination with local color and decay to the point of complete disregard of all modernizing efforts added an ambivalent tone to his rhetoric. In the Turkish Republican imaginary, Loti's persona was admired, yet his depictions were not welcome, and he became the target of staunch criticism $^{7}$. The celebrated poet Nazım Hikmet Ran famously called Loti a charlatan in his poem "Piyer Loti," contending that the Orient as Loti depicted it is a figment of imagination only: it has "never been, neither yesterday, nor today, or tomorrow" (Hikmet Ran) ${ }^{8}$.

6 "La touchante littérature personnelle du voyageur sensitif." Moura suggests the following points when establishing colonial literature as a sub-genre separate from exoticism: “La véracité et la pénétration; [...] la garantie d'être écrite par quelqu'un qui connait son sujet ; [...] l'approbation de la colonisation; [...] une affirmation de l'énergie morale du colonialisme," (Moura, pp. 113-114).

7 Loti's Turcophilia inspired a number of responses. For an overview, see İnci Enginün, "Loti'nin Türklere Bakışı ve Edebiyatçılarımızın Yorumu" [Loti's Perspective on the Turks and the Responses of Our Literary Figures]. The prominent ones are: Abdülhak Şinasi Hisar (1958) istanbul ve Pierre Loti. [Istanbul and Pierre Loti]. Orhan Koloğlu, (2001). Büyük Dost Pierre Loti'ye Mektuplar [Letters to the Great Friend, Pierre Loti]. İstanbul: Pierre Loti Dostları Derneği.

8 "ne dün/ ne bugün/ ne yarın yoktu, / olmayacak!" (Hikmet Ran, 1929). 
A study of a Western European's fascination with Istanbul as the capital of the Oriental Other, the present study alludes to Edward Said's Orientalism (1978) and its associated literature (Clifford, 1988; Hentsch, 1988; Said, 1994). The focus here, however, is affect: the claim to intimate knowledge of Ottoman Turkey, and the nuancing of exoticist imaginationimaginary. Loti's narratives on Ottoman Istanbul present a kaleidoscope of interests, identities and affiliations, making it worth reading in detail and from different angles. Aziyadé, arguably the most popular of these narratives, has been a popular topic of research following Roland Barthes's introduction to its Italian edition (Barthes, 1972). The essay focused mostly on the multiple orientations of its protagonist and the complex referentiality. By including Fantôme d'Orient in this reading of Loti's Turkish affinity, this study extends the scope of Barthes's work to further nuance the subject positions, to explore the role of memory, and to trace Loti's understanding of the city extends beyond its exoticism.

\section{Aziyadé}

\section{a. The Orient}

Loti's debut novel is an evocation of all that has built up the Oriental spell through the story of Loti's sojourn: subjection, splendor, loss and decay. The political subjection of the Ottomans forms both the background and a major theme in the novel, evoked on various levels, with substantial, albeit subjective, information on political and historical contexts. Aziyadé is set in 1876 and 1877, a period of crisis for the Ottoman Empire, marked by increasing Western European domination and control, as in the First Constitution in 1876 and the wars with Russia during 1876 and 1877 . The novel begins with a portrayal of the Ottoman Empire under the power of Western imperialism. The first impression is the group execution in Salonika, imposed by the French and German governments, as a reparation for the assassination of their consuls. What was once the terror of the West has withered into an empire in name only. Loti will soon have the privileged vantage point to observe it all as an officer and a gentleman, in this case a Turkish one.

Loti's love for a disappearing culture led to self-discovery. He recounts, "the Orient cast its great charm on the awakening of myself": the result is not immediately positive; the allure of the fading empire troubles the senses (Loti 1991, p. 41) ${ }^{9}$. The writer's

9 "L'Orient jetait son grand charme sur ce réveil de moi-même, qui se traduisait par le trouble des sens." 
impressions of the Ottoman Empire, however, are based on commonplaces, fantasies, and, in his words, 'enchantments.'Turkish habits and customs are portrayed through expressions as "la nonchalance Orientale," (Loti, 1991, p. 53) “le luxe oriental," or "l'élégance originale de I'Orient" (Loti, 1991, p. 74). The writer has no doubt that readers will understand what the adjectives signify. Writing for a Francophone audience, Loti's depictions conform to the Orientalist understanding, which in Edward Said's words, is "not so much the East itself as the East made known ... to the Western reading public"(Said, 1978, p. 60). Turkish 'sorrow' is another case, which, Loti notes, "need blood and blast" (Loti, 1991, p. 212) ${ }^{10}$. In a letter to a friend, Loti compares the 'Oriental' and 'Occidental' conceptions of privacy in interior living: "The Orientals know how to be alone at home; you live, in your houses in Europe, open to all the passers, as one lives on the streets here. You know neither the blessedness of the interior, nor the spell of this mystery" (Loti, 1991, p. 153) ${ }^{11}$. Fondness for Turkish customs is evident in the remarks on the "blessedness," and the "spell" of Turkish interior living, alongside repeated use of commonplace imagery. The Orient, even when qualifying the allure of Istanbul, appears an antithetical other through which the European traveler gets to reflect on the West.

\section{b. The Beloved and the City}

Notwithstanding occasional references to the politics of the period, the novel revolves around Loti's affair with Aziyadé, a young woman of Circassian origin, and the youngest of the four legal wives of a wealthy Turk. Loti steals a furtive glance at Aziyadé's"immense green eyes" behind the bars of her abode in the Turkish quarter of Salonika, and both are smitten. This love story in an exotic setting realizes one of the great Western fantasies - the harem. Forbidden and secluded, the ever-absent women of the harem have been a favorite theme of Western art, and their availability has been one of the great metaphors for the Western colonization of Islamic countries. The affair sounds like a fantasy, also because Aziyadé is not really a Turkish name, but a coinage of Loti, to protect the identity of his beloved. Aziyadé's nightly escapades from her house enable them to start a lifechanging relationship. Loti manages to arrange meetings with her. In this, Samuel, a poor Jew whom he had met also in Salonika, helps him. Samuel is an incarnation of the multiplicity of affinities: Turk by chance, Jewish by faith, and Spanish through his family

10 "Il parait qu'il faut du bruit et du sang aux douleurs turques."

11 "Les Orientaux, mon cher ami, savent seuls être chez eux; dans vos logis d'Europe, ouverts à tous venants, vous êtes chez vous comme on est ici dans la rue [...] vous ne connaissez point cette inviolabilité de l'intérieur, ni le charme de ce mystère." 
(Loti, 1991, p. 77). For Loti, Samuel evokes another Orientalist cliché, sodomy. In his Journal, and in the original manuscript, the sexual attraction is not an undertone but a key component of their relationship (Loti, 1991, p. 359) ${ }^{12}$. In the novel, however, samesex preference is mentioned in passing, as something dark, obscure, and unheard of. Loti exclaims: "in the Orient all is possible!" (Loti, 1991, p. 44) ${ }^{13}$. Evoking Edward Said's reference to the Orient as "a living tableau of queerness" (Said, 1978, p. 103), the Orient, constitutes the gate to forbidden pleasures, enabling re-orientation of various sorts, opening up space to negotiate the self as well as the other.

The next stop is Istanbul. Loti first stays in the modern Péra, but his heart is in the Turkish side of the city. He acquires a Turkish friend and a confidante, Achmet, with whom he discovers the discreet charm of Oriental life. He has already been dressing up in the traditional Turkish outfit and passing as a Turk in Salonika, thanks to his Jewish confidantes (Loti, 1991, p. 39). Loti continues the tradition in the metropolis. He also learns sufficient Turkish to pass himself off as Arif Effendi, an Ottoman of Albanian origin. He gets acquainted with Turkish customs, hanging around cafés, smoking hookah with the locals and joining in their discussions, and occasionally roaming the streets and cemeteries. Assuming a Turkish identity is a means of entertainment, if not an escapade. Loti refers to it as a child's play. He contends, "I play effendi, like children play soldiers" (Loti, 1991, p. 71) ${ }^{14}$. Playing with ethnic character exposes the theatricality, if not performativity of cultural identity. Here the aim is not surveying the Other, but taking part, in his words "to be oneself a part of this tableau so full of movement and of light" (Loti, 1991, p. 86) ${ }^{15}$. In this affirmation of multiple subject positions, Roland Barthes captures the goal of transvestism, and also the appeal of Loti's narrative: "to transform oneself into a describable object, not an introspectable subject" (Barthes, p. 11).

This particular practice of crossdressing possesses imperialist undertones as it exposes the Orient as a culture that the Western European easily masters, without the opposite being possible. In comparison to Loti's multiple personae and simultaneous access to the Orient and the Occident, Turkish characters appear monochrome and

12 "La tête de Samuel endormi était à mes pieds. Le sommeil lui avait imprimé une expression tranquille et grave; c'était la beauté antique dans toute sa pureté noble et sa perfection... Et j'oubliai Aziyadé en songeant à l'étrange lien qui m'attachait à cet homme".

13 "Quelque chose d'inouï et de ténébreux avait un moment passé dans la tête du pauvre Samuel; dans le vieil Orient tout est possible!"

14 "Je joue à l'effendi, comme les enfants joue aux soldats."

15 "Etre soi-même une partie de ce tableau plein de mouvement et de lumière" 
limited. Loti's familiarity with and fondness for Turks does not impede him from including a cluster of tropes that justify the empire and the hierarchies it enables. In Istanbul, following a period of restless waiting, Loti is finally accompanied by Aziyadé. They settle in Eyoub, the predominantly Muslim neighborhood with beautiful vistas of the Golden Horn. From then on, the city and the beloved converge, evoking the typical literary trope of feminizing the city. With abundant descriptions of Istanbul and the Turks, Aziyadé recounts Loti's doomed love for a city, a culture, and a woman, accompanied by the emergence of an Oriental identity.

\section{c. Love of eski}

Despite Pierre Loti's affinity with and access to the popular Turkish views on politics, his perspective remains highly Eurocentric: every major political event, for him, is a Western machination. He considers the First Constitution of 1876 a decree dictated by England and France, in contradistinction to Ottoman political traditions, and therefore without legitimacy in the eyes of the Turks. All attempts at democracy are against the essence of the Ottoman Empire, and nothing more than mere Western pretensions. Loti claims: "Turkey will lose much of its originality with the application of this new system" (Loti, 1991, p. 111) ${ }^{16}$. The constitution, part of the modernizing reforms of the Empire, was in fact declared against Western European machinations. Nonetheless, Loti is clearly not interested in the complexities of the Empire. Nor does he seem to be aware of the democracy seeking Turks and other ethnic groups that constituted a sizeable part of the population of his beloved city.

The Turks, as Loti sees them, revere eski: the old. They love the past, stagnation, and immobility (Loti, 1991, p. 112) ${ }^{17}$. Alongside the spell and the pleasures of life à la turque, then, Aziyadé is the story of one man's acute sense of the impending loss. His world is one in decline, and nothing that he cherishes will last; neither his affair with Aziyadé, nor his 'Turkish'life. The idyllic life falls to pieces upon Loti's departure. Forsaken, Aziyadé dies soon after. Loti returns later to Istanbul, to find that all that he has cherished is lost. His lover and friends are dead, and the Ottoman Empire is engaged in a futile war with Russia. 'Oriental life' now gone, Loti joins the Turkish army against the Russians, and is killed in the war. The novel ends in devastation. Loti as the Turkish subject cannot avoid destruction and death. Yet as the French author, he dictates death. The dual

16 "Au point de vue de son originalité, la Turquie perdra beaucoup à l'application de ce nouveau système."

17 "Les Turcs ont l'amour du passé, l'amour de l'immobilité et de la stagnation." 
perspective illustrates the ambiguity of his affinities and the hierarchies the rhetoric of empire enabled.

\section{Fantôme d'Orient}

\section{a. Return as Pilgrimage}

Aziyadé ends with the death of the protagonists. Its closure, however, awaited its writer's second visit and an encounter with his Turkish life. Fantôme d'Orient, the account of Loti's three-day stay in Istanbul ten years after the publication of Aziyadé, was written in 1887 and published in 1891. The account of this journey, written in the form of a diary, finally brought a sense of resolution to his life a la Turque. Despite his longing for Istanbul and his identification with its cultures, Loti's return to the city is not a belated homecoming. Nor is this a simple visit or a commemoration. It is a devotional duty, "a pilgrimage [he had] been dreaming of for the past ten years" (Loti, 1991, p. 246) ${ }^{18}$. Considered the saddest of all Loti's work, and by some his masterpiece, the Fantôme d'Orient is a narrative of redemption, repentance and memory (Quélla-Villeger, p. 135).

The complexity of Loti's narrative has to do with the nature of his fondness for Istanbul. His Turcophilia is a multi-layered attachment; the sights and sounds of the city blend with the memories of his beloved Circassian. ${ }^{19}$ Yet, this love is doomed as both are perishable. In his mind, something of him died when he left Aziyadé and Istanbul and was buried in Turkish lands. The pilgrimage is therefore an encounter with the past, an implausible return to this old self. Loti's Turkish life has disappeared: the neighborhood he lived in has changed, Aziyadé's home is burnt down in one of the many fires that devastate the wooden houses, his friends are dead, and their traces are far and few. Death seems ubiquitous, yet it is not devastating. The encounter with the past strangely brings memories of spring and love (Loti, 1991, p. 269) ${ }^{20}$. As the book progresses, love and death morph into a certain redemption.

Loti finds Aziyadé's tomb, at the end of a long walk along the byzantine walls of the city. The encounter with death is cathartic. Shedding warm tears, he repents and

18 "Un pèlerinage auquel, depuis dix ans, je rêve."

19 "Tout ce qui en [Aziyadé] vient, [...] aussitôt me plonge dans une rêverie d'exilé où réapparaît Stamboul!"

20 "C'est étrange que ces choses de la mort, parce qu'elles sont demeurées telles quelles, ravivent en moi précisément des souvenirs de printemps et d'amour." 
reconciles with the past. Absolved of unkept promises, Loti is no longer haunted by recurring dreams of returning to Istanbul. From then on, the troubling ghost of the Orient becomes a friendly one. Through the reconciliatory ending, Loti's arguably saddest book transforms into one of his most optimistic narratives. Nonetheless, the photographs of his much-documented home in Rochefort and his multiple interviews attest to a different outcome; during the same visit, Loti replaced Aziyadé's tombstone, and took the original with him, to display in his Oriental room (Vercier, 1999). This unusual memento mori attests to the complexity of Loti's feelings regarding Aziyadés death. The insistence to keep the tombstone as a souvenir of the past connotes an acute sense of loss, invoking Freud's distinction between normal and pathological responses to loss. Freud contends that in mourning "it is the world that has become poor and empty, in melancholia it is the ego itself" (Freud, p. 286). It might as well be that the visit to the cemetery represents the moment when Loti finally faced Aziyadé's death as an actuality, and not merely his fantasy, perhaps turning the melancholy of half-acknowledged loss into incomplete mourning.

Istanbul and the liaison with Aziyadé frame Loti's exploration of the fugitive, the ephemeral, and the moribund. Loti's poetics of return and fascination with death and decay constitute the main problematic in his work. Mortality and destruction are indeed prominent themes that recur in Loti's fiction (Hargreaves, p. 42). From a historical standpoint, the deaths of the primary characters in Loti's debut novel and their later confirmation in the travel narrative foreshadow the impending destruction of the Empire and of the Turkish subjecthood that Loti identified with. Nonetheless, his 'exoticism' is composed at the expense of the Turks who, by their ever-changing, diverse and complex human nature, defy all generalizations. Just as the besieged Sardanapalus, he has his subjects killed before his own eyes (Hentsch, p. 216). Similarly, his repentant attitude towards his Turkish life is reminiscent of the paradox of imperialist nostalgia as defined by Renato Rosaldo: "a person kills somebody, and then mourns the victim" (Rosaldo, p. 69). Nonetheless, Loti's personal attachment to the victim and his unusual mourning go beyond nostalgia, revealing the intricate links between love, loss and death.

\section{b. Cosmopolitan Istanbul}

A relatively unnoticed reward of reading Fantôme d'Orient is the insights into the cosmopolitan cultures of Istanbul. Loti confesses, in a tone not unrelated to the devotional tone of the visit, that the depictions of his Turkish life in Aziyadé are not entirely correct. 
We find out that in Istanbul, after leaving the cosmopolitan Galata, Loti lived in Hasköy, the traditional Jewish neighborhood dating back to the Jewish expulsion from Spain in $1492^{21}$. The Jewish connection, probably relating to his stay in Salonica and his relations with Samuel, is one of the key themes he admits he omitted from Aziyadé. Loti claims the main reason for the omission is his insistence on brevity, but also the status of the area at the time (Loti, 1991, p. 277). The observation regarding the reputation of Hasköy is astute; from the second half of the nineteenth century onwards, the upwardly mobile Jewish families increasingly preferred to move to more modern and affluent neighborhoods like Péra and Galata. The descriptions of the city and its communities provide further instances into the idiosyncratic cosmopolitanism of the Oriental metropolis as it shaped its historical neighborhoods. The Golden Horn may be considered, architectural historian Zeynep Çelik contends, as the demarcation between Ottoman Istanbul and Levantine Péra, between the old and the new, the 'locals' and the 'westerners' (Çelik, p. 160)22. Péra has a relative absence of mosques, whereas in the old city, domes and minarets delineate the skyline. Urban structure on both sides, however, was similar: both had narrow, winding streets, which somehow maintained their medieval forms. Notwithstanding some of the architectural features, this divide was mainly topographical; neither side of the Golden Horn was exclusive to one ethnic or religious group (Almas, 2011).

The omission of the predominantly Jewish neighborhood from the debut novel reveals the scope of Loti's understanding of the metropolis. The narrative downplays the city's cosmopolitanism by disregarding a peculiar interchangeability between Turkish and Jewish, notably Sephardi, identity. Fantôme d'Orient reinstates it, adding that conviviality includes different ethnicities in the metropolis as well. Loti's search for his past involves his Turkish friends, notably Ahmet, his close friend and Turkish teacher. Loti visits Ahmet's family and finds out that he has passed away. To pay him his respect, Loti visits the cemetery, a venue that dominates the narrative, also featuring in many of the typical images of the city. This time however, we are not in Muslim territory. Ahmet's sister reminds the writer that her brother was a Catholic Armenian who'turned Turk',yet who remembered Christ just before his death (Loti, 1991, p. 322). By introducing the multiethnic cultures of his Turkish life in Aziyadé, Loti nuances both his initial story

21 Hasköy flourished with the arrival of the Sephardim following the expulsion in 1492. Its earliest depiction as a predominantly Jewish neighborhood is by Evliya Çelebi in the seventeenth century.

22 See (Almas, 2011) for an extended discussion on the significance of the Golden Horn and the bridging of its two sides in relation to the twentieth-century imaginary of Istanbul as a city where East meets West. 
and Istanbul's complex cosmopolitanism. The writer's attachment to the city might be encapsulated in between the lines of this self-reflexive narrative, and in confessions as follows: "Istanbul is the only city in the world where I was really blended into the life of its people - to the lives of its colorful, oriental, noisy, picturesque, yet poor, needy, bustling people" (Loti 1991, p. 278) ${ }^{23}$. Loti's account affirms that for the visitors to the Ottoman capital, there was no clash of binary opposites between the local and the foreigner, but rather"a wide spectrum of identities from which individuals had to choose their own place" (Fuhrmann, p. 8). A true metropolis, Loti's Istanbul offers multiple points of affiliation, if not identification. The city that Loti celebrates and laments for in this retrospective text emerges as a contact zone, in the sense that Mary Louise Pratt defines the term: a"social space where disparate cultures meet, clash, and grapple with each other" (Pratt, p. 9). Fantôme d'Orient is not simply a remembrance of things past. It reflects on the debut novel, beckoning a rereading, and providing multiple vantage points to the city and to the narrative. Loti no longer plays effendi, nor does he try to be a part of the tableau. Instead, he reviews the pretense of a Turkish self and the tableau that he felt he was part of. Only then does he fully acknowledge the mosaic composed by the cultures of the millennial metropolis.

\section{Conclusion}

Cultural reorientation involves desire, disorder, and disconcertment, with the promise of renewal. Set in fin de siècle Ottoman Turkey on the eve of its disintegration, Loti's Aziyadé and Fantôme d'Orient marks the 'death' of an era, and of a certain image of "the Turk."Yet, the writer's fascination with eski, the old, and with the local color cause him to miss out on the germination of a modern state. The Republic of Turkey, founded in 1923 as a westernized, secular, and democratic country, presented a 'Turk' closer to the European self than the Ottoman 'Turk' ever was. The imagery of Turks and Istanbul may therefore be read as a snapshot of the imagination imaginary of the period, bearing witness to its cataclysms, and heralding imminent metamorphosis. The dual perspective illustrates the conflict, albeit complementary, concerning Loti's affinities. Aziyadé demonstrates the Turkish protagonist's inability to avoid death, and the French author capitalizes on it. Fantôme d'Orient revisits that past and puts it to rest, while ironically encouraging Loti to focus on what he sees in his patrie orientale, rather than on his reveries.

23 "C'est que Constantinople est la seule ville du monde ou j'ai été vraiment mêlé à la vie du peuple, à la vie de ce peuple oriental, bruyant, coloré, pittoresque, mais besoigneux, pauvre, actif à mille petits métiers, à mille petits brocantages." 
The Turkish identity of Pierre Loti appears as primarily an affective and emotional stance. His representation of Ottoman Turkey perpetuates the existing set of values and images associated with the Turks. Just as the Turkish Room, with which I started this paper, lacks the Oriental spell despite his first-hand experience of Turkey, and as such evokes the movie sets or "kitsch" Oriental fantasies, as does Aziyadé and Fantôme $d^{\prime}$ Orient. With respect to his Turkish room, Loti admits that he has somehow failed to capture the spell of the Orient. Whatever he does, he is unable to bring the Oriental Charm to his room in Rochefort. He protests: "this is not the Orient; whatever I did, I haven't been able to bring its charms here. It's missing the light, something that cannot be replicated" (Genet, Hervé; p. 341) ${ }^{24}$. The photograph bears witness to this case of failed mimicry: the typical Turkish outfit and the typical Turkish room have little in common with its re-presentation.

Regardless of their autobiographical quality and referentiality, Loti's narratives reinforce Oriental stereotypes and commonplaces. Based on essentialist views, both narratives confine the Turks to the typical Orientalist imagery of despotism and inertia, albeit contradictory, romanticized and highly exotic. Turcophilia does not preclude Loti from adopting an Orientalist perspective; yet, it seems to have made him respect, admire, and acknowledge the otherness of his subject. Disconcerting and desirable, a source of disorder and doubt, the encounter with the Turkish other for Loti, and for the western traveler holds the promise of renewed encounter with the self.

Peer-review: Externally peer-reviewed.

Conflict of Interest: The author has no conflict of interest to declare.

Grant Support: The author declared that this study has received no financial support.

Hakem Değerlendirmesi: Dış bağımsız.

Çıkar Çatışması: Yazar çıkar çatışması bildirmemiştir.

Finansal Destek: Yazar bu çalışma için finansal destek almadığını beyan etmiştir.

24 "Ce n'est pas Orient, j'ai beau faire, le charme n'y est pas venu. Il y manque la lumière, un je ne sais quoi du dehors qui ne s'apporte pas." 


\section{References}

Almas, H. E. (2011). Capitalizing Istanbul: Reading Orhan Pamuk's Literary Cityscape. (Doctoral dissertation, The University of Amsterdam). Retrieved from http://www.dare.uva.nl/document/2/97299.

Armbrecht, T.J. D. (2003) The Nostalgia of Nowhere: Pierre Loti's Utopian Spaces. Mosaic: An Interdisciplinary Critical Journal, 36(4), 81-102.

Ashcroft, B., G. Griffiths, and Tiffin H. (Eds.). (2000). Post-colonial Studies: Key Concepts. New York: Routledge. Barthes, R. (1972). Aziyadé. Le degré zéro de l'Ecriture. [Zero Degree of Writing]. Paris: Seuil.

Clifford, J. (1988). The Predicament of Culture, Massachusetts: Harvard University Press.

Çelik, Z. (1986). The Remaking of Istanbul: Portrait of an Ottoman City in the Nineteenth Century. Seattle: University of Washington Press.

Deringil, S. (2003). 'They Live in a State of Nomadism and Savagery': The Late Ottoman Empire and the PostColonial Debate. Comparative Studies in Society and History, 45(2) (April), 311-42.

Enginün, I. Loti'nin Türklere Bakışı ve Edebiyatçılarımızın Yorumu [Loti's Perspective on the Turks and the Responses of Our Litterateurs]. Pierre Loti Toplantı Bildirileri. http://ekitap.kulturturizm.gov.tr/TR,80378/inci-engunu.html.

Freud, S. (1917). Mourning and Melancholia. In J. Radden (Eds.), The Nature of Melancholy: From Aristotle to Kristeva (pp. 283-94). New York: Oxford University Press, 2000.

Fuhrmann, M. (2020). Port Cities in the Eastern Mediterranean, Cambridge: Cambridge University Press. Genet, C. \& Hervé, D. (1988). Pierre Loti l'enchanteur, [Pierre Loti, the enchanter]. Aubin, Poitiers: la Caillerie, Gémozac. Hargreaves, A. (1981). The Colonial Experience in French Fiction: a study of Pierre Loti, Ernest Psichari, and Pierre Mille. London: Mac Millan Press.

Hentsch, T. (1988). L'Orient Imaginaire: la vision politique occidentale de l'Est méditerranéen [Imaginary Orient: the western political vision of the Mediterranean East]. Paris: Minuit.

Hikmet, N. (2007). Piyer Loti. Bütün Şiirleri, Istanbul: Yapı Kredi Yayınları.

Hisar, A. Ş. (1958). Istanbul ve Pierre Loti. [Istanbul and Pierre Loti]. İstanbul: Yapı Kredi Yayınları, 2004.

Koloğlu, O. (2001). Büyük Dost Pierre Loti'ye Mektuplar [Letters to the Great Friend, Pierre Loti]. İstanbul: Pierre Loti Dostları Derneği.

Lévi-Strauss, C. (1955) Tristes Tropiques. Paris: Plon.

Lewis, R. (2004). Rethinking Orientalism: Women, Travel and the Ottoman Harem. New Brunswick: Rutgers University Press.

Loti, P. (1991). Aziyadé suivie par le fantôme d'Orient. Paris: Gallimard.

---. (1990). Constantinople en 1890. Istanbul: Isis Yayınevi.

---. (1924). Les Désenchantées. Paris: Calmann-Lévy.

Moura, J.-M. (1997). L'Europe et l'ailleurs littéraire [Europe and literary elsewhere]. Paris: Presses Universitaires Françaises.

Quella-Villéger, A. (2002). Pierre Loti, Gezegen Seyyahı. Trans. Aysel Bora. [Pierre Loti, the pilgrim of the planet] Istanbul: Yapı Kredi Yayınları. 
Pratt, M. L. (2008). Imperial Eyes: Travel Writing and Transculturation. London: Routledge.

Rosaldo, R. (1993). Culture and Truth: The Remaking of Social Analysis. Boston: Beacon Press.

Said, E. (1994). Culture and Imperialism. London: Vintage.

---. (1978). Orientalism: Western Conceptions of the Orient. London: Penguin.

Şerifoglu, O. F. (ed). (2004). Hanedandan Bir Ressam: Abdülmecid Efendi [A Painter in Court: Abdülmecid Effendi]. Istanbul: Yapı Kredi Yayınları.

Spurr, D. (1999). The Rhetoric of Empire: Colonial Discourse in Journalism, Travel Writing and Imperial Administration. Durham: Duke University Press. 
